\title{
Microbial Attributes of Infested Soil Suppressive to Bacterial Wilt by Bokashi Amendments
}

\author{
Mariana R. Fontenelle, Carlos A. Lopes, Carlos E. P. Lima, Daiane C. Soares, \\ Luciana R. B. Silva, Daniel B. Zandonadi, Ronessa B. Souza, Antônio W. Moita \\ Embrapa Hortaliças/CNPH, Brasília, Brazil \\ Email: mariana.fontenelle@embrapa.br
}

Received 10 September 2015; accepted 25 October 2015; published 28 October 2015

Copyright (C) 2015 by authors and Scientific Research Publishing Inc.

This work is licensed under the Creative Commons Attribution International License (CC BY). http://creativecommons.org/licenses/by/4.0/

(c) () Open Access

\section{Abstract}

Bacterial wilt, caused by Ralstonia solanacearum, is a major tomato disease in tropical and subtropical regions. It is difficult to be managed, since no single measure confers significant contribution for disease control. Among the cultural practices available for disease management, bokashi provides nutrients to the plants, increasing the microbial biomass, improving the quality of the soil and, in some cases, protecting plants against diseases. In this work, we evaluated the effect of three different bokashis (Embrapa-BE; poultry-BP and cattle-BC) in two soils artificially and naturally infested with $R$. solanacearum, on the suppression of bacterial wilt in tomato. Disease control is discussed upon measurements on the contents of microbial biomass carbon (MBC), on total organic carbon (TOC), on basal respiration (BR), on metabolic coefficient $\left(\mathrm{qCO}_{2}\right)$ and on microbial coefficient (qMIC). The experiment was implemented in greenhouse, with completely randomized design and factorial arrangement of treatments $2 \times 3$ (two soils $\times$ three bokashis). Disease suppression, assessed through wilt incidence 20 and 30 days after transplanting, was better observed in the naturally infested soil, where BP and BE were more efficient in controling the disease. TOC contents were higher in the artificially infested soil compared to that naturally infested, whereas the qMIC presented higher value for the naturally infested soil, which had greater contribution of MBC. Higher rates of $\mathrm{BR}$ and $\mathrm{qCO}_{2}$ were observed for the naturally infested soil with $\mathrm{BC}$, probably indicating high plant stress caused by the disease in this treatment. Moreover, a high and positive correlation coefficient was found between the variables $\mathrm{qCO}_{2}$ and the number of infected plants at 30 days after transplanting. In the artificially infested soil, a negative correlation was found between the number of infected plants at 20 days after transplanting and TOC.

\section{Keywords}

Basal Respiration, Disease Control, Microbial Biomass, Ralstonia solanacearum,

How to cite this paper: Fontenelle, M.R., Lopes, C.A., Lima, C.E.P., Soares, D.C., Silva, L.R.B., Zandonadi, D.B., Souza, R.B. and Moita, A.W. (2015) Microbial Attributes of Infested Soil Suppressive to Bacterial Wilt by Bokashi Amendments. Agricultural Sciences, 6, 1239-1247. http://dx.doi.org/10.4236/as.2015.610119 


\section{Solanum lycopersicum}

\section{Introduction}

Bacterial wilt, caused by Ralstonia solanacearum, has been a limiting factor for the tomato crop (Solanum lycopersicum) in regions of high temperature associated to high soil moisture, which frequently occurs in locations of low altitude in the North and Northeast Regions of Brazil. More recently, it has been a matter of concern for producers of protected cultivation, where crop rotation, one of the main control strategies, is not properly adopted for economic reasons [1].

Bacterial wilt is a very difficult disease, especially due to the great pathogenic variability of the bacterium, its capacity of surviving in the soil, and the large number of its host species [2]. Once introduced in an area, eradication of the bacterium is very difficult; there are reports that $R$. solanacearum persists in the soil for more than ten years in the absence of Solanaceae species by surviving in the rhizosphere of various cultivated species or weeds [3] [4].

Information on the survival period of the pathogen in the soil is scarce and rather conflicting, an expected phenomenon considering that the soil is a complex entity, altered in time and space by various biotic and abiotic factors and by their interactions. Therefore, among other factors, survival period depends on the type of soil, the organic ones providing more rapid decline, probably due to their higher microbial activity [5] [6].

The existence of soils presenting suppression of bacterial wilt suggests that biological control is a field to be better explored for the purpose of integrated control [7]. Besides, soil microorganisms are of extreme importance for the cycling of nutrients [8]. The use of organic fertilizers such as bokashis, which composition contains macro- and micronutrients that are made available to the plants [9], stimulate an increase in microbial biomass in vegetable crops, improving the quality of the soil in several aspects.

In addition to supplying nutrients, bokashi also contains microorganisms. They are developed according to a record by TeruoHiga from the University of Ryukyus in Okinawa, Japan [10]. The fertilizer is composed of crumbled and fermented organic materials, using inoculum obtained from leaf litter, commonly denominated EM (effective microorganisms), which is rich in bacteria, yeasts, actinomycetes, photosynthetic bacteria and other organisms occurring naturally in the environment [11]. The ecology of these microorganisms is very dependent on the chemical, physical and biological composition of the soil, but it has been reported that such microbes play a relevant role in the natural or induced suppression of the soil, a rather complex phenomenon that results in reduction of the deleterious effects of various phytopathogenic microorganisms [12]. In the preparation of a bokashi, the microorganisms act on the organic matter and ferment it [13], with the consequent production of organic acids, vitamins, enzymes, amino acids and polysaccharides important for plant growth. However, the role of bokashi controling plant disease still unclear.

The application of organic compounds results in improvement of the microbial biomass and its activity in the soil, compared to the use of chemical fertilizers [14] [15]. The application of bokashis in potato induced significant responses up to a dose of $400 \mathrm{~g} \cdot \mathrm{m}^{-2}$, with yield of $24.5 \mathrm{t} \cdot \mathrm{ha}^{-1}$; however, it did not influence the dry matter content and the incidence of physiological disorders [16]. In organic systems, EM-bokashi reduced germination of fungal spores and the incidence of anthracnose in bell pepper. In the production of organic coffee, seedlings with bokashi at $2 \%$, weekly complemented with EM at $0.1 \%$, developed $38 \%$ more than in the conventional system, where soluble fertilizers were applied every 15 days and mancozeb and benomyl every week [17].

Microbial biomass, activity, and diversity are features used to characterize the biological component of the soils. The microbial biomass represents about $2 \%-5 \%$ of the total organic carbon (TOC) of the soils [18]. Evaluation of the microbial biomass, together with determination of the metabolic state of the microorganism community, provides useful information about the levels of microbial activity.

Although studies on the association of treatments with bokashi reveal gains in productivity and promising responses to the attack of phytopathogens, little is known regarding the direct or indirect relationships with the plant and the pathogens. Knowledge about the size of the microbial community, as well as its activity in the soils under treatment with different bokashis, allows inferring about the carbon balance flows in organic agriculture and elucidates part of the involved biological processes. Moreover, it may generate results that enable assumptions regarding the relationship between the microbes and the suppression of diseases in the soil, for instance 
bacterial wilt.

The present work had the objective of assessing the microbial attributes in soils naturally or artificially infested with Ralstonia solanacearum amended with three bokashis upon different levels of suppressiveness to bacterial wilt.

\section{Materials and Methods}

\subsection{Description of the Area and Experimental Design}

The experiment was carried out in the autumn of 2013, in greenhouse at Embrapa Vegetables, situated at the rural area of Gama, Distrito Federal (DF, Brazil; geographical coordinates $15^{\circ} 56^{\prime} \mathrm{S}$ and $48^{\circ} 08^{\prime} \mathrm{W}$; altitude $997.6 \mathrm{~m}$ ). The temperature in the greenhouse was maintained between $20^{\circ} \mathrm{C}$ and $40^{\circ} \mathrm{C}$ by natural ventilation and artificial night heating in order to provide adequate conditions for disease establishment and evolution. The tomato plants were cultivated in plastic crates of $40 \times 20 \times 10 \mathrm{~cm}$ with capacity for approximately $10 \mathrm{~kg}$ of soil. The experimental design was in completely randomized plots (CRD), each represented by one crate, with four replications in a $2 \times 3$ factorial arrangement, with two soils (artificially and naturally infested) and three bokashis (cattle bokashi—BC, poultry bokashi—BP, and anaerobic bokashi produced at Embrapa Vegetables—BE).

\subsection{Soil Infestation with Ralstonia solanacearum and Collection of the Contaminated Soil}

The artificially infected soil was obtained from the experimental field of Embrapa Vegetables. The soil is of Rhodic Ferralsol type, supplemented with $10 \mathrm{~L}$ of raw straw, $10 \mathrm{~L}$ of burned straw, and $187.5 \mathrm{~g}$ of limestone/100 $\mathrm{L}$ of soil, autoclaved and later infested with the isolate RS 489, race 1, biovar 1, phylotype II of $R$. solanacearum, obtained from wilted tomato plants produced in Borrazópolis (PR, Brazil). Soil infestation was accomplished by planting inoculated seedlings of tomato "San Vito", susceptible to bacterial wilt, produced in Styrofoam trays with 128 cells containing the commercial substrate Bioplant ${ }^{\circledR}$ and exhibiting three definitive leaves. For inoculation, the seedlings were removed from the trays and their roots, exposed in the substrate blocks, were sprayed with a bacterial suspension containing approximately $10^{8} \mathrm{UFC} / \mathrm{mL}$, prepared by culturing the bacterium on Kelman medium without tetrazolium [19] for $48 \mathrm{~h}$ at $28^{\circ} \mathrm{C}$. Twelve inoculated seedlings were planted in each crate and placed in a greenhouse. Fifteen days after inoculation, the plants, then wilted by action of the pathogen, were removed and new seedlings of tomato "San Vito", at the stage of three definitive leaves, were immediately planted, with nine plants per tray, now without artificial inoculation. For the purpose of testing eventual suppression by the treatments, the crates were considered infested after noticing that, 20 days after transplantation, the majority of the non-inoculated seedlings began presenting symptoms of the disease. By means of the exudation test, [20] it was confirmed that wilting was indeed caused by $R$. solanacearum.

The naturally infested soil, of Dystric Cambisol, was collected at the city of Alexânia (DF, Brazil), in field cultivated with tomato where severe epidemics of bacterial wilt occurred. Samples were collected with a shovel in the plant hills after removal of the wilted plants. For transport, the samples were placed into plastic bags and transferred to the plastic crates in the same day. Samples taken from symptomatic plants revealed the presence of race 1 , biovar 1 , phylotype II of $R$. solanacearum.

\subsection{Application of Bokashi}

The different bokashis were incorporated into each type of infested soil and, 20 days later, 12 "San Vito" tomato seedlings were transplanted to the crates. The amount of added bokashi was determined by the contents of $\mathrm{N}$ in the organic fertilizer (Table 1), as well as the requirement of the tomato crop used to conduct the experiment. The added amounts were $450 \mathrm{~g} / \mathrm{crate}$ of BE, $460 \mathrm{~g} / \mathrm{crate}$ of BP, and $650 \mathrm{~g} / \mathrm{crate}$ of BC per experimental allotment. BC and BP were acquired from third parties (product commercialized in the Federal District-DF, Brazil). Their composition includes plant scraps, effective microorganisms (EM) and fertilizers that differ in relation to their origin, cattle or poultry (BC and BP, respectively). BE is the result of anaerobic decomposition of organic debris, composed of plant scraps, EM and poultry litter, besides other organic compounds such as bone powder, castor bean cake. The water supply was maintained at field capacity, based on measurements by moisture sensors placed in each crate immediately after seedling transplantation into both types of infested soils. Disease incidence, given by the percentage of wilted plants, was assessed at 20 and at 30 days after transplantig. Collection 
Table 1. Total contents of nutrients present in three bokashis evaluated for control of tomato bacterial wilt.

\begin{tabular}{ccccccccccccc}
\hline Bokashi & N & P & K & Ca & Mg & S & B & Cu & Fe & Mn & Zn \\
\hline \multicolumn{7}{c}{$\left(\mathrm{g} \cdot \mathrm{kg}^{-1}\right.$ soil) } \\
BP & 28.6 & 5.1 & 8.4 & 18.7 & 5.0 & 1.8 & 225.0 & 64.9 & 13333.3 & 255.8 & 204.2 \\
BE & 31.0 & 10.3 & 18.1 & 60.2 & 17.5 & 3.4 & 123.3 & 57.3 & 2725.0 & 332.5 & 267.5 \\
BC & 12.8 & 1.7 & 3.0 & 6.0 & 2.3 & 0.8 & 262.5 & 51.6 & 16166.7 & 54.3 & 105.0 \\
\hline
\end{tabular}

of the soil was performed after two tomato cycles.

\subsection{Determination of the Microbiological Attributes}

For analysis of MBC, the moisture of each sample was determined by gravimetric difference, calculated between dry and natural moisture samples, after $72 \mathrm{~h}$ in incubator at $110^{\circ} \mathrm{C}$. Soil samples of $20 \mathrm{~g}$ were then weighed. Subsequently, water was added to maintain the moisture at $100 \%$ of field capacity. The MBC was determined by the chloroform-fumigation-incubation method [21] [22]. Each sample was prepared in triplicate, three fumigated (F) and three non-fumigated (NF). Determination of TOC content was accomplished by the method of Walkley-Black. The evolution of $\mathrm{C}-\mathrm{CO}_{2}$ was established in $\mathrm{mg}$ of $\mathrm{C} / \mathrm{kg}$ of dry soil from the volume spent in the titration of the NF samples. $\mathrm{qCO}_{2}$ was calculated by the ratio between $\mathrm{C}-\mathrm{CO}_{2}$ and $\mathrm{MBC}$ per day [23] and qMIC by the ratio between MBC and TOC [24].

\subsection{Statistical Analyses}

The normality of data distribution was evaluated and basal respiration variable was transformed to $\log (x+1)$, before performing ANOVA. Treatments were tested for significance difference using Scott-Knott test with a probability level of $\mathrm{P}=0.05$. The data for number of infected plants at 20 days was not normally distributed, even after transformation. Thus, Kruskal-Wallis and Mann-Whitney U non-parametric tests were used for their analysis with a probability level of $\mathrm{P}=0.05$.

\section{Results and Discussion}

The conditions under which the experiments were carried out, considering the tomato cultivar, the levels of infestation of the soils and the combination temperature $\times$ soil moisture, allowed the manifestation of bacterial wilt in adequate intensity for the objectives of the assay. No effect on statistical variation source (type of soil and bokashis) were verified on the MBC contents (Table 2). Effects were only noticed for the types of soil on the contents of TOC, the relation qMIC, and the number of infected plants at 20 days. Effects on statistical variation source (type of soil and bokashis) were also verified on the basal respiration. Moreover, statistical interaction between the factors was significant only for the variables $\mathrm{qCO}_{2}$ and infected plants at 30 days after plant exposition to the pathogen (Table 3).

The artificially infested soil yielded higher number of infected plants at 20 and 30 days; in the latter, when treated with BP and BE. No differences were observed between the mean numbers of infected plants at 30 days when the soils were treated with BC. Therefore, it is evidenced that the naturally infested soil presented greater suppression of bacterial wilt at the beginning of the cycle premise that held true to the end of the tomato cicle except when BC was used. This result is in accordance with those by Coca et al. [25], who detected greater reduction of bacterial wilt by poultry litter in comparison to cattle manure in Ferralsol of potato field naturally infested with $R$. solanacearum. Our data do not support conclusions about the cause of different responses of bokashis towards suppression to bacterial wilt. Most probably, they might be related to favoring peculiar microbial compositions that regulate the population of the pathogen, as well as to special fractions of its organic matter that may alter plant nutrition and rhizobiome composition. These are possibilities to be investigated in future research.

The obtained data further suggest that the initial suppression (at 20 days) of bacterial wilt was mostly dependent on type of soil, without significant influence of the bokashis. However, it is not possible to infer about the 
Table 2. Microbial biomass carbon and basal respiration of one soil artificially or naturally infested with Ralstonia solanacearum, fertilized with bokashis and cultivated with tomato plants.

\begin{tabular}{|c|c|c|c|c|c|}
\hline Source of variation & $\begin{array}{c}\mathrm{MBC} \\
\left(\mathrm{mg} \cdot \mathrm{C} \cdot \mathrm{kg}^{-1} \text { soil }\right)\end{array}$ & $\begin{array}{c}\text { TOC } \\
\left(\mathrm{g} \cdot \mathrm{kg}^{-1}\right)\end{array}$ & $\begin{array}{c}\text { qMIC } \\
\left(\mathrm{mg} \cdot \mathrm{MBC}^{-\mathrm{g}^{-1}} \mathrm{C} \text { soil }\right)\end{array}$ & $\begin{array}{l}\text { Basal respiration }\left({\mathrm{C}-\mathrm{CO}_{2}}^{*}\right) \\
\left(\mathrm{mg} \cdot \mathrm{C} \cdot \mathrm{kg}^{-1} \text { soil }\right)\end{array}$ & $\begin{array}{l}\text { Number of wilted plants } \\
\text { at } 20 \text { days }\end{array}$ \\
\hline \multicolumn{6}{|l|}{ Soil infestation } \\
\hline Artificial & $242.73^{\mathrm{ns}}$ & $118.80 \mathrm{a}$ & $2.08 \mathrm{~b}$ & $11.52 \mathrm{~b}$ & $4.25 \mathrm{a}$ \\
\hline Natural & $273.01^{\mathrm{ns}}$ & $80.02 \mathrm{~b}$ & $3.46 \mathrm{a}$ & 19.81 a & $0.67 \mathrm{~b}$ \\
\hline \multicolumn{6}{|l|}{ Bokashis } \\
\hline BP & $235.47^{\mathrm{ns}}$ & $95.66^{\text {ns }}$ & $2.75^{\mathrm{ns}}$ & $15.25 \mathrm{~b}$ & $2.50^{\mathrm{ns}}$ \\
\hline $\mathrm{BE}$ & $302.53^{\text {ns }}$ & $105.03^{\text {ns }}$ & $2.95^{\mathrm{ns}}$ & $12.75 \mathrm{~b}$ & $1.50^{\mathrm{ns}}$ \\
\hline $\mathrm{BC}$ & $235.60^{\mathrm{ns}}$ & $97.54^{\mathrm{ns}}$ & $2.59^{\mathrm{ns}}$ & 18.98 a & $3.38^{\mathrm{ns}}$ \\
\hline CV (\%) & 32.3 & 15.39 & 30.07 & 19.82 & 52.30 \\
\hline
\end{tabular}

Means followed by the same letter (column) do not differ by the Scott-Knott test at 5\% (MBC, TOC, qMIC and basal respiration) or the Mann- Whitney $\mathrm{U}$ test at $5 \%$ (infected plants after 20 days). ${ }^{\text {ns }}$ Non-significant by the $\mathrm{F}$ test at 5\% (MBC, TOC, qMIC and basal respiration) or Kruskal-Wal- lis test at $5 \%$ (infected plants after 20 days). *Data transformed by the function $\mathrm{y}=\log (\mathrm{x})$ for analysis. BE-Bokashi from Embrapa Vegetables; BP-Poultry bokashi; BC—Cattle bokashi; MBC—Microbial biomass carbon; TOC—Total organic carbon; qMIC—Microbial coefficient.

Table 3. Metabolic coefficient and number of wilted plants cultivated in soil artificially or naturally infested with Ralstonia solanacearum, fertilized with bokashis and cultivated with tomato plants.

\begin{tabular}{|c|c|c|c|}
\hline \multicolumn{4}{|c|}{ Metabolic coefficient $\left(\mathrm{qCO}_{2}\right)\left(\mathrm{mg} \cdot \mathrm{C}-\mathrm{CO}_{2} \cdot \mathrm{mg}^{-1} \mathrm{MBC} \cdot \mathrm{day}^{-1}\right)$} \\
\hline Soil infestation & $\mathrm{BP}$ & $\mathrm{BE}$ & $\mathrm{BC}$ \\
\hline Artificial & $0.066 \mathrm{aA}$ & $0.038 \mathrm{aA}$ & $0.057 \mathrm{bA}$ \\
\hline Natural & $0.064 \mathrm{aB}$ & $0.054 \mathrm{aB}$ & $0.122 \mathrm{aA}$ \\
\hline \multicolumn{4}{|c|}{ CV $(\%)=30.28$} \\
\hline \multicolumn{4}{|c|}{ Number of wilted plants at 30 days } \\
\hline & $\mathrm{BP}$ & $\mathrm{BE}$ & $\mathrm{BC}$ \\
\hline Artificial & $6.50 \mathrm{aA}$ & $4.75 \mathrm{aA}$ & $6.75 \mathrm{aA}$ \\
\hline Natural & $2.25 \mathrm{bB}$ & $0.25 \mathrm{bB}$ & $6.75 \mathrm{aA}$ \\
\hline \multicolumn{4}{|c|}{$\mathrm{CV}(\%)=38.40$} \\
\hline
\end{tabular}

Means followed by the same lowercase (column) or capital letter (row) do not differ by the Scott-Knott test at 5\%. BE—Bokashi from Embrapa Vegetables; BP_-Poultry bokashi; BC_Cattle bokashi; MBC—Microbial biomass carbon.

interaction between those factors on the suppression, since the absence of normal distribution of the data led to the necessity of using non-parametric statistical tests, thus restricting the identification of possible interaction effects. At the final evaluation (at 30 days), however, a significant interaction was observed for the factors types of soil and bokashi In this last assessment, lack of effect of the bokashis was observed on the incidence of infected plants in the artificially contaminated soil; differently, BP and BE were efficient in partially controlling the disease in the naturally infected soil. Hence, it could be established that the bokashis had suppressive effect on the number of infected plants at 30 days only when added to the naturally infested soil. It deserves mention that the artificially infested soil was previously sterilized by heating. Studies have shown that soils suppressive to Rhizoctonia solani, when heatedat $80^{\circ} \mathrm{C}$, lose their suppression capacity. In these studies, 33,000 species of archae bacteria and bacteria associated to suppression were identified, such as Proteobacteria (Pseudomonadaceae, Burkholderiaceae, Xanthomonadales), Firmicutes (Lactobacillaceae) and Actinobacteria [26].

MBC contents were not affected by either bokashi or soil types. It is possible that the conduction of two short cycles with the tomato plant, under the adopted experimental conditions, was not sufficient for statistical differences to be detected. Although MBC can be considered a variable responsive to alterations in short-term man- 
agement, its response is more intense in long-term experiments [27].

Higher TOC contents were observed in artificially infested soils compared to naturally infested ones. These results are probably related to the types of soil, Rhodic Ferralsol and Dystric Cambisol, respectively. Ferralsol commonly present elevated contents of $\mathrm{Fe}$ and $\mathrm{Al}$ oxyhydroxides and strong and granular structure [28]. Therefore, the higher TOC contents may be associated to the stabilization promoted by intermolecular links between the organic matter and oxyhydroxides [29] and/or physical protection against microbial decomposition by occlusion in stable aggregates [30] [31].

The qMIC, an index expressed by the relation between MBC and TOC [32], presented higher value for the naturally infested soil than for the artificially infested one. In the latter, although TOC is smaller, the carbon associated to the microbial biomass is more elevated, as observed by Powlson et al. [33]. The contribution of the microbial biomass for the organic matter composition was greater in the naturally infested soil. The higher microbial biomass in it may be associated to the greater microbial population previously existent in the soil. On the other hand, in the artificially previously sterilized infested soil, after addition of the bokashis the microbial population had to be reestablished with microorganisms resistant to the treatment, pathogenic agents added via inoculation, and microorganisms existent in the specific bokashis. This probably hindered the increment in this soil's microbial biomass and yielded a lower qMIC value.

Effects of the soils and bokashis isolatedly on the basal respiration were identified. The highest basal respiration rates were found for the naturally infested soil. The analysis of effects of the bokashis on this variable showed that BC presented the highest rates, followed by BP and BE, which did not differed between them.

For $\mathrm{qCO}_{2}$, effects of interaction between the studied factors were observed. The highest $\mathrm{qCO}_{2}$ was found when the naturally infested soil was treated with BC. It is worth to point out that the highest values of qMIC were identified for this same soil. Also the highest values of basal respiration were registered for this soil and bokashi isolatedly. Further, the addition of $\mathrm{BP}$ and $\mathrm{BE}$ did not promote different values of $\mathrm{qCO}_{2}$ in the naturally infested soil, while none of the three bokashis influenced the values of this variable in the artificially infested soil.

$\mathrm{qCO}_{2}$ is an index that expresses the relationship between basal respiration and amount of microbial biomass per day [32]. The increase in the values for this variable may indicate that, in stress situations, here related to the manifestation of bacterial wilt, the major part of the carbon is used to provide energy instead of being assimilated and converted into new microbial biomass, evidencing a greater demand for carbon [23]. Increases in the carbon: potassium ratio and in the carbon concentration in the soil also seem to influence the increase in $\mathrm{qCO}_{2}$ [34]. It is possible, therefore, that these results reflect a lower capacity of BC of suppressing the $R$. solanacearum population in the naturally infested soil and, consequently, the occurrence of bacterial wilt, thus increasing the stress condition evidenced by the higher $\mathrm{qCO}_{2}$. This theory is reinforced by the high and direct coefficient of correlation found between the variables $\mathrm{qCO}_{2}$ and number of infected plants at 30 days (Table 4) in the naturally infested soil. The significant and positive coefficient of correlation between the number of infected plants 20

Table 4. Correlation coefficients of Spearman (IP 20 days) and Pearson (IP 30 days) between the variables analyzed for one soil artificially or naturally infested with Ralstonia solanacearum.

\begin{tabular}{ccccc} 
& \multicolumn{2}{c}{ Artificially infested soil } & \multicolumn{2}{c}{ Naturally infested soil } \\
\hline IP 20 days & IP 30 days & IP 20 days & IP 30 days \\
TOC & $0.00^{\mathrm{ns}}$ & $0.43^{\text {ns }}$ & $-0.18^{\mathrm{ns}}$ & $-0.54^{\mathrm{ns}}$ \\
qMIC & $-0.63^{*}$ & $0.01^{\text {ns }}$ & $-0.12^{\mathrm{ns}}$ & $-0.51^{\mathrm{ns}}$ \\
Basal respiration & $0.14^{\mathrm{ns}}$ & $0.38^{\mathrm{ns}}$ & $-0.06^{\mathrm{ns}}$ & $0.37^{\mathrm{ns}}$ \\
qCO & $0.19^{\mathrm{ns}}$ & $0.42^{\mathrm{ns}}$ & $0.56^{*}$ & $0.53^{\mathrm{ns}}$ \\
IP 20 days & $0.12^{\mathrm{ns}}$ & $-0.18^{\mathrm{ns}}$ & $0.50^{\mathrm{ns}}$ & $0.70^{*}$ \\
IP 30 days & 1 & $0.30^{\mathrm{ns}}$ & 1 & $0.63^{*}$ \\
\hline
\end{tabular}

*Significant at 5\% probability; ${ }^{\text {ns }}$ non-significant at 5\% probability. IP_-Infected plants; MBC-Microbial biomass carbon; TOC—Total organic carbon; qMIC—Microbial coefficient; $\mathrm{qCO}_{2}$-Metabolic coefficient. 
days and the basal respiration also seems to support this theory. At last, a significant and positive coefficient of correlation was also found between the number of plants infected at 20 and at 30 days in naturally infested soil, suggesting that, in this case, when controlled at its initial stages by the addition of BP and BE, bacterial wilt presented less severity. Altogether, the results agree with those observed by Lwin and Ranamukhaarachchi [35], who reported the presence of microorganisms antagonist to $R$. solanacearum through application of commercial EM inocula or bokashis.

In the artificially infested soil, the only significant coefficient of correlation found was the negative one between the number of infected plants at 20 days and TOC. This relation seems to infer that, when a diverse biomass is absent, as this soil was sterilized beforehand, the organic matter of the soil becomes the main mechanism of suppression of bacterial wilt; yet, it seems to have greater importance at the initial stage of the disease. Nevertheless, the higher infection rate at the two stages examined for this soil seems to indicate that the mechanisms associated to the suppression promoted by the increase in TOC contents and, consequently, its compounds, are less effective than those related to a higher and more biodiverse microbial community, as observed in the naturally infested soil. It should be remarked that this is a preliminary work. Other hypotheses must not be neglected, in order for future tests to be carried out in order to elucidate the complex phenomenon of disease suppressiveness in soils. One of the many examples of variables that may interfere with results in this kind of studies is the $R$. solanacearum isolate. It might be more fit to the specific soil condition or more resistant to components responsible for the suppressiveness processes. The smaller biodiversity in the artificially infested soil resulted in lower suppressive action against the pathogen, so the pathogen population was able to grow more rapidly due to lack of competition for resources with other microorganism populations. Moreover the amount of inoculum used to artificially infest the soil was probably higher than in the naturally infested soil, thus reducing the suppressive capacity of the bokashis. Independently on the amendment used, this work strongly indicated that the analysis of results in relation to the suppression of the bacterial wilt by organic additives in artificially infested soils, especially when previously sterilized, should be done with caution, since they may not represent the real suppression capacity.

\section{Conclusion}

Soil naturally infested with $R$. solanacearum provided a more reliable test for bacterial wilt suppressiveness by addition of organic additives as compared with a soil artificially infested. Different bokashi formulations have distinct capacity to reduce bacterial wilt incidence on tomato plants. Disease incidence reduction by bokashi application in soil is partial and cannot be seen as a sole method of bacterial wilt control in tomato. Higher bacterial wilt suppression was evidenced in a naturally infested soil treated with the bokashis from Embrapa Vegetables and from poultry litter, as compared to cattle bokashi. Basal respiration was higher upon addition of cattle bokashi to the soil; moreover, the metabolic coefficient was higher for cattle bokashi in the naturally infested soil, evidencing the presence of higher plant stress and higher disease incidence. Direct relation was found between TOC content and bacterial wilt incidence in the artificially infested soil, suggesting that, when the initial biomass was reduced, the organic compounds were the main agents of $R$. solanacearum suppression.

\section{Acknowledgements}

We would like to thank Damião Fernandes da Cunha, Wagner Ribeiro Viana and Pedro Maria Basílio do Amaral for technical assistance. This work was funded by Embrapa.

\section{References}

[1] Lopes, C.A. (2015) Bacterial Wilt-A Threatening Disease of Tomato Cultivated under Warm Temperatures. Brasília. Comunicado Técnico Embrapa Hortaliças, 109.

[2] Hayward, A.C. (1994) The Hosts of Pseudomonas solanacearum. In: Hayward, A.C. and Hartman, G.L. (Eds.), Bacterial Wilt: The Disease and Its Causative Agent, Pseudomonas solanacearum, CAB International, Wallingford, 9-24.

[3] Crosse, J.E. (1967) Plant Pathogenic Bacteria in Soil. In: Gray, T.R.G. and Parkinson, D., Eds., The Ecology of Soil Bacteria, University Press, Liverpool, 552-572.

[4] Quezado-Soares, A.M. and Lopes, C.A. (1994) Lack of Control of Potato Bacterial Wilt by Avirulent Mutants of Pseudomonas solanacearum and by Fluorescent Pseudomonads. Bacterial Wilt Newsletter, 11, 3-5.

[5] Moffet, M.L., Giles, J.E. and Wood, B.A. (1983) Survival of Pseudomonas solanacearum Biovars 2 and 3 in Soil: Ef- 
fect of Moisture and Soil Type. Soil Biology and Biochemistry, 15, 587-591.

http://dx.doi.org/10.1016/0038-0717(83)90054-8

[6] Kado, C.I. (2010) Plant Bacteriology. APS Press, St. Paul, 336 p.

[7] French, E.R. (1994) Strategies for Integrated Control of Bacterial Wilt of Potatoes. In: Hayward, A.C. and Hartman, G. L., Eds., Bacterial Wilt: The Disease and Its Causative Agent, Pseudomonas solanacearum, CAB International, Wallingford, 199-207.

[8] Gomes, W.R. and Pacheco, E. (1988) Composto orgânico. Escola Superior de Agricultura de Lavras. Lavras. Boletim técnico, 11.

[9] Garcia-Sánchez, M., Garcia-Romera, I.,Cajthaml, T., Tlustoš, P. and Száková, J. (2015) Changes in Soil Microbial Community Functionality and Structure in A Metal-Polluted Site: The Effect of Digestate and Fly Ash Applications. Journal of Environmental Management, 162, 63-73. http://dx.doi.org/10.1016/j.jenvman.2015.07.042

[10] Higa, T. and Parr, J.F. (1994) Beneficial and Effective Microorganisms for a Sustainable Agriculture and Environment. Vol. 1, International Nature Farming Research Center, Atami.

[11] Ahn, K., Lee, K., Kim, Y., Koo, Y. and Korean, J. (2014) Quantitative Analysis of the Three Main Genera in Effective Microorganisms Using qPCR. Korean Journal of Chemical Engineering, 31, 849-854. http://dx.doi.org/10.1007/s11814-013-0274-6

[12] Hadar, Y. and Papadopoulou, K.K. (2012) Suppressive Composts: Microbial Ecology Links between Abiotic Environments and Healthy Plants. Annual Review of Phytopathology, 50, 133-153. http://dx.doi.org/10.1146/annurev-phyto-081211-172914

[13] Alattar, M.A., Green, T.R., Henry, J., Gulca, V., Tizazu, M., Bergstrom, R. and Popa, R. (2012) Effect of Microaerobic Fermentation in Preprocessing Fibrous Lignocellulosic Materials. Applied Biochemistry and Biotechnology, 167, 909917. http://dx.doi.org/10.1007/s12010-012-9717-5

[14] Vinhal-Freitas, I., Wangen, D.R.B., Ferreira, A.S., Corrêa, G.F. and Wendling, B. (2010) Microbial and Enzymatic Activity in Soil after Organic Composting. Revista Brasileira de Ciência do Solo, 34, 757-764. http://dx.doi.org/10.1590/s0100-06832010000300017

[15] Chaudhry, V., Rehman, A., Mishra, A. and Chauhan, P.S. (2012) Changes in Bacterial Community Structure of Agricultural Land Due to Long-Term Organic and Chemical Amendments. Microbial Ecology, 64, 450-460. http://dx.doi.org/10.1007/s00248-012-0025-y

[16] Ishimura, I., Tivelli, S.W., Alves, H.S., Ramos, V.J. and Yamamoto, S. (2010) Influência de níveis do biofertilizante bokashi e do ativador de crescimento Trichoderma na produção de batata orgânica. Horticultura Brasileira, 28, S2741S2745.

[17] Chagas, P.R.R. and Tokeshi, H. (2006) Produção orgânica utilizando-se bokashi e microrganismos benéficos (EM) no controle de pragas e doenças. Paper presented at III Cobradan-Congresso Brasileiro de Defensivos Agrícolas Naturais, Belém, PA. http://www.cpmo.org.br/artigos/producao_organica_bokashi_paulo_chagas.pdf

[18] Jenkinson, D.S. and Ladd, J.M. (1981) Microbial Biomass in Soil: Measurement and Turnover. In: Paul, E.A. and Ladd, J.M., Eds., Soil Biochemistry, Marcel Dekker, New York, 415-471.

[19] Kelman, A. (1954) The Relationship of the Pathogenicity of Pseudomonas solanacearum to Colony Appearance on a Tetrazolium Medium. Phytopathology, 44, 693-695.

[20] Lopes, C.A. and Ávila, A.C. (2005) Doenças do tomateiro. Embrapa Hortaliças, Brasília.

[21] Jenkinson, D.S. and Powlson, D.S. (1976) The Effects of Biocidal Treatments on Metabolism in Soil—V. A Method for Measuring Soil Biomass. Soil Biology and Biochemistry, 8, 209-213. http://dx.doi.org/10.1016/0038-0717(76)90005-5

[22] Jenkinson, D.S. and Powlson, D.S. (1976) The Effects of Biocidal Treatments on Metabolism in Soil-I. Fumigation with Chloroform. Soil Biology and Biochemistry, 8, 167-177. http://dx.doi.org/10.1016/0038-0717(76)90001-8

[23] Anderson, T.H. and Domsch, K.H. (2010) Soil Microbial Biomass: The Eco-Physiological Approach. Soil Biology and Biochemistry, 42, 2039-2043. http://dx.doi.org/10.1016/j.soilbio.2010.06.026

[24] Sparkling, G.P. (1992) Ratio of Microbial Biomass Carbon to Soil Organic Carbon as a Sensitive Indicator of Changes in Soil Organic Matter. Australian Journal of Soil Research, 39, 195-207. http://dx.doi.org/10.1071/SR9920195

[25] Coca, D.M. (2001) Efeito da adubação orgânica em batata (Solanum tuberosum L.) cultivada em solo infestado com Ralstonia solanacearum biovar I. Master’s Thesis, Universidade de Brasília, Brasília, DF.

[26] Mendes, R.M.K., Bruijn, I., Dekkers, E., van der Voort, M., Schneider, J.H.M., Piceno, Y.M., DeSantis, T.Z., Andersen, G.L., Bakker, P.A.H.M. and Raaijmakers, J.M. (2011) Deciphering the Rhizosphere Microbiome for DiseaseSuppressive Bacteria. Science, 332, 1097-1100. http://dx.doi.org/10.1126/science.1203980

[27] Silva, R.R., Silva, M.L.N., Cardoso, E.L., Moreira, F.M.S., Curi, N. and Alovisi, A.M.T. (2010) Biomassa e atividade 
microbiana em solo sob diferentes sistemas de manejo na região fisiográfica Campos das Vertentes—MG. Revista Brasileira de Ciência do Solo, 34, 1585-1592. http://dx.doi.org/10.1590/s0100-06832010000500011

[28] Schaefer, C.E.G.R., Fabris, J.D. and Ker, J.C. (2008) Minerals in the Clay Fraction of Brazilian Latosols (Oxisols): A Review. Clay Minerals, 43, 1-18. http://dx.doi.org/10.1180/claymin.2008.043.1.11

[29] Wiseman, C.L.S. and Püttmann, W. (2006) Interactions between Mineral Phases in the Preservation of Soil Organic Matter. Geoderma, 134, 109-118. http://dx.doi.org/10.1016/j.geoderma.2005.09.001

[30] Conceição, P.C., Boeni, M., Bayer, C., Dieckow, J., Salton, J.C. and Reis, C.E.S. (2015) Efficiency of the Dense Solutions in Physical Fractionation of Soil Organic Matter. Revista Brasileira de Ciência do Solo, 39, 490-497. http://dx.doi.org/10.1590/01000683rbcs20140447

[31] Bayer, C., Mielniczuk, J., Giasson, E., Martin-Neto, L. and Pavinato, A. (2006) Tillage Effects on Particulate and Mineral-Associated Organic Matter in Two Tropical Brazilian Soils. Communications in Soil Science and Plant Analysis, 37, 389-400. http://dx.doi.org/10.1080/00103620500446928

[32] Dinesh, R., Srinivasan, V., Hamza, S., Manjusha, A. and Kumar, P.S. (2012) Short-Term Effects of Nutrient Management Regimes on Biochemical and Microbial Properties in Soils under Rainfed Ginger (Zingiber officinale Rosc.). Geoderma, 173-174, 192-198. http://dx.doi.org/10.1016/j.geoderma.2011.12.025

[33] Powlson, D.S., Brookes, P.C. and Christensen, B.T. (1987) Measurement of Soil Microbial Biomass Provides an Early Indication of Changes in the Total Soil Organic Matter Due to Straw Incorporation. Soil Biology and Biochemistry, 19, 159-164. http://dx.doi.org/10.1016/0038-0717(87)90076-9

[34] Spohn, M. and Chodak, M. (2015) Microbial Respiration per Unit Biomass Increases with Carbon-to-Nutrient Ratios in Forest Soils. Soil Biology and Biochemistry, 81, 128-133. http://dx.doi.org/10.1016/j.soilbio.2014.11.008

[35] Lwin, M. and Ranamukhaarachchi, S.L. (2006) Development of Biological Control of Ralstonia solanacearum through Antagonistic Microbial Populations. International Journal of Agriculture and Biology, 8, 657-660. 